\title{
Role of inland fishery and aquaculture for food and nutrition security in Nepal
} CrossMark

\author{
Tek Bahadur Gurung*
}

\begin{abstract}
Fish as a food is generally acceptable to all regardless of region, religion, race, gender and age across Nepal. The aquaculture and open-water capture fishery contributes about $2 \%$ of agricultural gross domestic production; this share of fisheries sector is tiny but promising having a fastest 8-9 \% annual growth rate. Nevertheless, the contribution of fisheries sector is big from nutritional security perspective to poor and marginalized communities and thus cannot be ignored. Generally, the role and importance of the inland water fisheries had been rarely elaborated with perspectives to food and nutritional security in Himalayan landlocked country. Therefore, the aim of this paper was to elucidate the role and potential of inland fisheries for food and nutrition security in Nepal. Information was collected from secondary sources to estimate per capita fish consumption. The per capita consumption was calculated dividing the total fish production by population of specific year, which showed that per capita fish consumption has increased from $125 \mathrm{~g}$ in 1975 to $2060 \mathrm{~g}$ in year 2013, at least nine times below compared with average global consumption. The value of per capita fish consumption would increase, if native shellfish (gastropod, crab, shrimp, and turtle), frogs and aquatic plants such as foxnut (Euryale ferox) and water chest nut (Trapa sp) which are consumed by ethnic communities are added. In the fish production among the five development regions of the country, Central Development Region was at the top, while Far-Western Development Region was at the bottom. However, on altitudinal basis southern plains contribute highest production, while least is in mountain areas although potentiality of cold-water aquaculture seems high. These imply that support services and innovation should be extended in the Western Development Region and mountainous regions in addition to the plains for improving fisheries-based food and nutrition security.
\end{abstract}

Keywords: Inland, Fishery, Aquaculture, Nepal, GDP, Per capita availability

\section{Background}

Nepal's total fish production from captured and aquaculture together is estimated to be about 64,900 metric tons in year 2013/2014 with the share of $33.17 \%$ to capture fisheries [40]. Aquaculture is the farming and husbandry of fish and aquatic organisms [6] where, with some intervention, increase in yield is expected with some form of ownership [8]; contrarily, the fish stocks in capture fisheries remain as a common property until harvested [5]. The term "fish" indicate fish, crustaceans, mollusks, frogs and turtles, excluding crocodiles, alligators, aquatic mammals and aquatic plants [13]. Captured fishery is one of the ancient approaches of food and nutrition supply

*Correspondence: tek_fisheries@hotmail.com

National Animal Science Research Institute, Nepal Agricultural Research Council, Kathmandu, Nepal contrarily to aquaculture which has been started lately. Almost all fish produced are consumed as food in Nepal.

Recent health benefit reports on $\omega-3$ or N-3 fatty acids found in fish food have probably been one of the major triggers of increasing fish demand. Fish is a rich source of animal protein, amino acids, folic acids, $\omega-3$, vitamins and micronutrients useful for health benefit to all age group [27, 37, 46, 50], especially for brain development, memory, mental and cardiac health [45, 48], working against Alzheimer disease and dementia $[33,36]$. The $\omega-3$ polyunsaturated fatty acid reduces free fatty acids, plasma triglyceride, cholesterol concentrations and platelet aggregation leading to decreasing blood pressure, blood clotting and atherosclerosis [37, 48].

The Government of Nepal has recommended at least $30 \mathrm{~g}$ per day fish or animal protein diet to each man, women, adolescent girls and boys [13]. Compared with 
the recommendation the fish intake is still far below than the recommended amount, suggesting that fish production needs to be promoted for productivity and production enhancement. The importance of fish over meat, poultry and eggs is due to low level of saturated fatty acids [7]. Thus, the role of fish products is immense in macroand micronutritional security [44], maintaining the health and nutrition of the global community from brain cells development to reducing chances of cardiac failure and enormous other health benefits $[13,14,29,33]$.

Nepal underlies as one of the food and nutrition-deficient countries. It has been estimated that $41 \%$ of Nepalese children suffer from stunting or chronic malnutrition $[17,31]$, having potential negative impact on the human population and economic development. Poor nutrition is cited as the major factor in more than half of all child deaths in Nepal-a significantly higher proportion than those claimed by other infectious diseases [17]. In early 1990s, the Nepalese standard food intake had very small amount of fish in their diet, but recently the amount of fish protein in common people diets is increasing [30]. This suggests that the fish production, availability, affordability, purchasing capacity and awareness might have led the increased consumption, implying that the role of fisheries in food and nutritional security is becoming indispensable and increasing. Coinciding with these facts, the Agriculture Development Strategy (2015-2030) has included fish as one of the prioritized commodities [2].

Recent technological innovation in cold-water aquaculture using rainbow trout (Oncorhynchus mykiss) has demonstrated that vast pristine Himalayan cold-water resources could be utilized for fish production [20]. Despite high potentiality for inland fisheries and aquaculture development, fish as a quality source of macro- and micronutritional food has yet to establish among a large section of population in Nepal. The role and importance of fisheries in Himalayan landlocked country, where fish symbolizes for fertility and prosperity, were rarely elaborated for food and nutritional security. Therefore, the aim of the present work is to transact and elucidate the per capita fish consumption for emphasizing the role and potential of fishery and aquaculture for food and nutritional security.

\section{Methods}

Data on fish production were obtained from the Directorate of Fisheries Division, Government of Nepal, Fisheries Research Division, and Bureau of Agricultural Statistics Division [40]. The data on population of Nepal and different developmental regions were collected from Ministry of Population. Information on various fish products such as fish oil, fish meal, canned food and fresh fishes was available in various places and supermarkets in Nepal.
The per capita consumption of fish was calculated using the standard method derived from the total national production divided by the number of inhabitants:

Fish consumption per capita $=$ total national production/number of inhabitants, where the total national production is fin fish yield from aquaculture practices and capture fisheries yield.

Similarly, the annual growth of inland fish production was estimated using the formula:

$$
\begin{aligned}
\text { Growth rate }(\%)= & (\text { Total fish production current year } \\
- & \text { total fish production previous year }) \times 100 / \\
& \text { Total fish production current year. }
\end{aligned}
$$

Information on various aquatic products consumable in different agroecological regions of Nepal such as pila (Pila globosa), bivalve (Lammelidens marginelis), crabs, shrimp, frogs (Paa liebigii, Paa blanfordii), turtle, Makhan (Euryale ferox) and water chest nuts (Trapa spp.) was collected from various studies. The average value of major nutrients and micronutrients in fish products was derived from various publications.

\section{Results and discussion}

\section{Fish production and consumption}

Nepal is a country with 27 million people surrounded by India and China with the unique altitude ranging from $68 \mathrm{msl}$ elevation to highest mountains peak of the world within an area of about $885 \mathrm{~km}$ long and $193 \mathrm{~km}$ width. Nepal has approximately $17 \%$ of flat land located in southern end commonly known as "tarai," while toward the north $83 \%$ is occupied by hills and mountains (Fig. 1). The vertical zonation for fish and fisheries activities and potential is shown in Fig. 2. The tarai is the site for carp, tilapia and catfish (Pangas, Clarias and others) production, while in lower mid-hills, carp along with cool-water fish species such as Mahseer (Tor spp) and Katle (Acrossocheilus hexagonolepis) could be cultivated. Asla or cold water cyprinids (Shizotharax spp) and rainbow trout (Oncorhynchus mykiss) in mid-hills can be produced in areas where glaciers waters with suitable low temperature are available, while upper regions represent the domains of the rainbow trout. In extremely cold waters above 2300-5000 meters range, probably arctic charr (Salvelinus alpinus) could perform well; however, studies require to be carried out on before reaching any conclusion (Fig. 2).

Fish production in Nepal is gradually increasing with a growth rate of $8-9 \%$ per year reaching $64,900 \mathrm{mt}$ in year 2013/2014 (Fig. 3a, b). Out of the total, the contribution of the capture fishery was $33.17 \%$ and rest $66.83 \%$ from the culture practices. The value of fish production includes the quantity of fin fish produced in the country. 

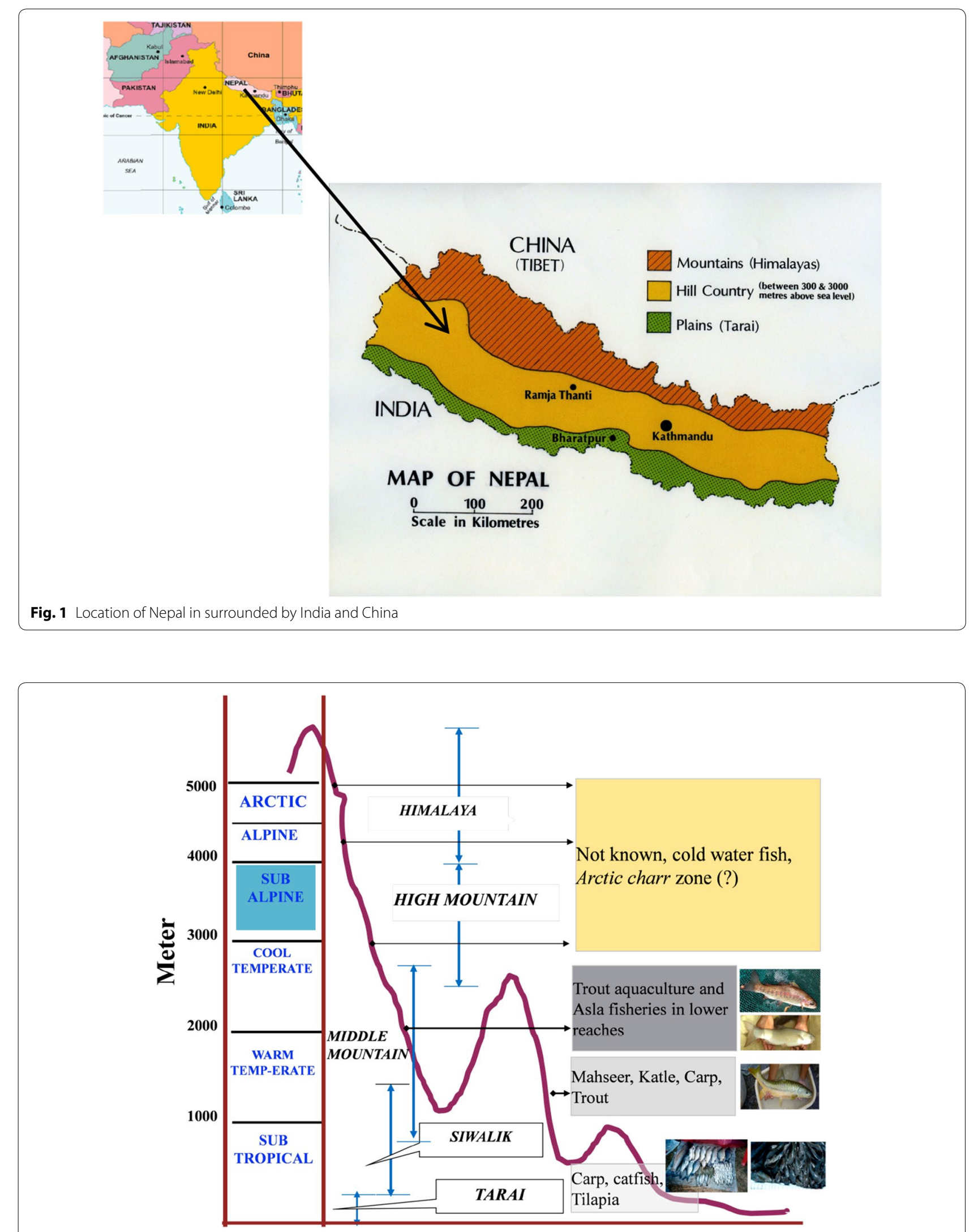

Fig. 2 Fisheries zoning in different altitudes of Nepal 

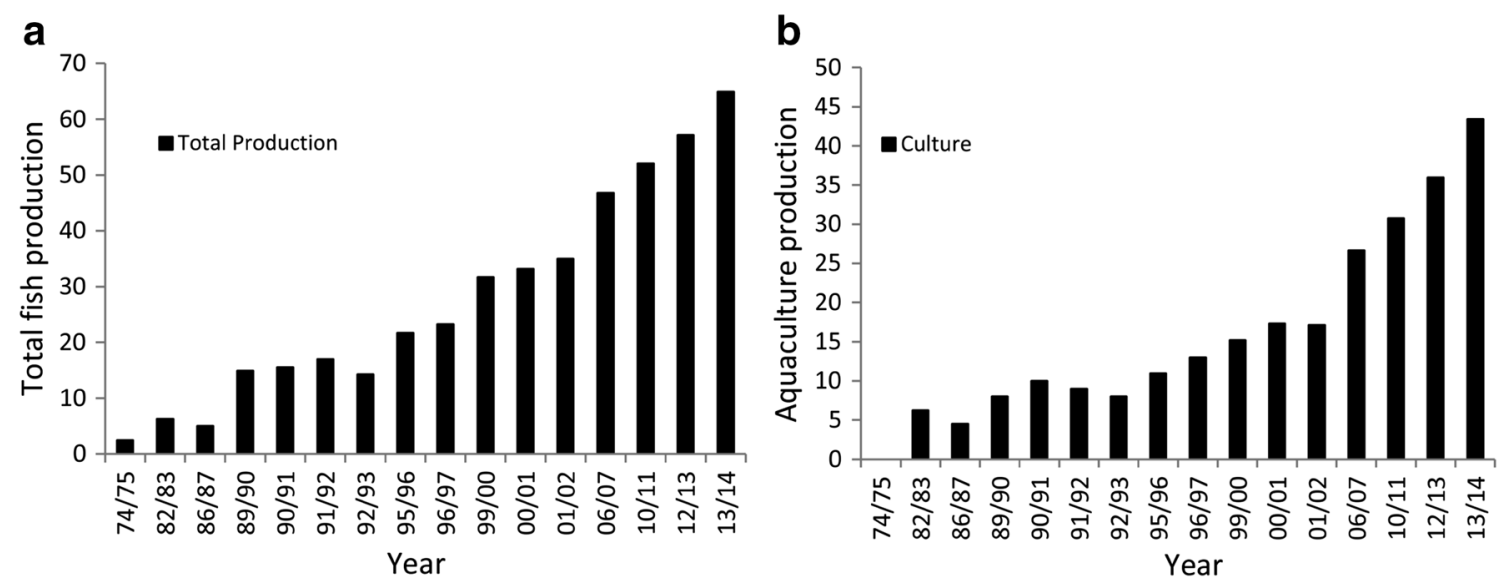

Fig. 3 Total fish production (aquaculture + captured fish) (a) and only aquaculture production (b) in Nepal (unit in x'000 metric ton)

The temporal changes in fish consumption showed steadily increasing despite the higher pace of the population growth (Fig. 4). The per capita fish consumption in 1975 was $194 \mathrm{~g}$ per day per year, after 39 years in 2013/2014 that has increased to $1983 \mathrm{~g} \mathrm{~d}^{-1} \mathrm{yr}^{-1}$ (Fig. 4). However, the fish consumption declined slightly in year 2013-2014, probably due to low fish production caused by unexpected devastating flood in tarai resulting heavy loss (Fig. 4). The per capita consumption of the fish in various parts of the country (Fig. 5) showed that highest fish consumption was in Central Development Region (1730 g), then in Eastern Development Region (1129 g), Western Development Region (1037 g), Mid-Western Development Region (762 g), and least in Far-Western Development Region (354 g). The per capita consumption of fish in Nepal represents only fin fish captured and cultured within the country. However, the per capita consumption in different development regions only represents those produced by means of aquaculture practices excluding the capture fishery.

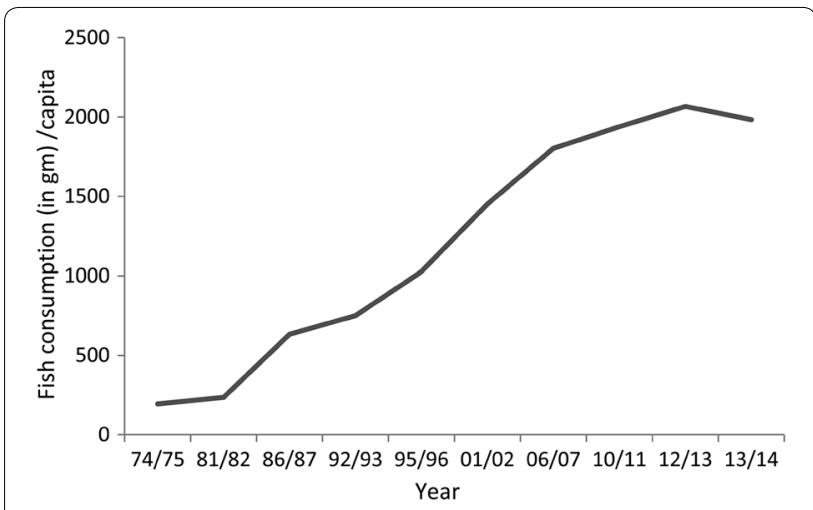

Fig. 4 Temporal changes in per capita fish consumption in Nepal

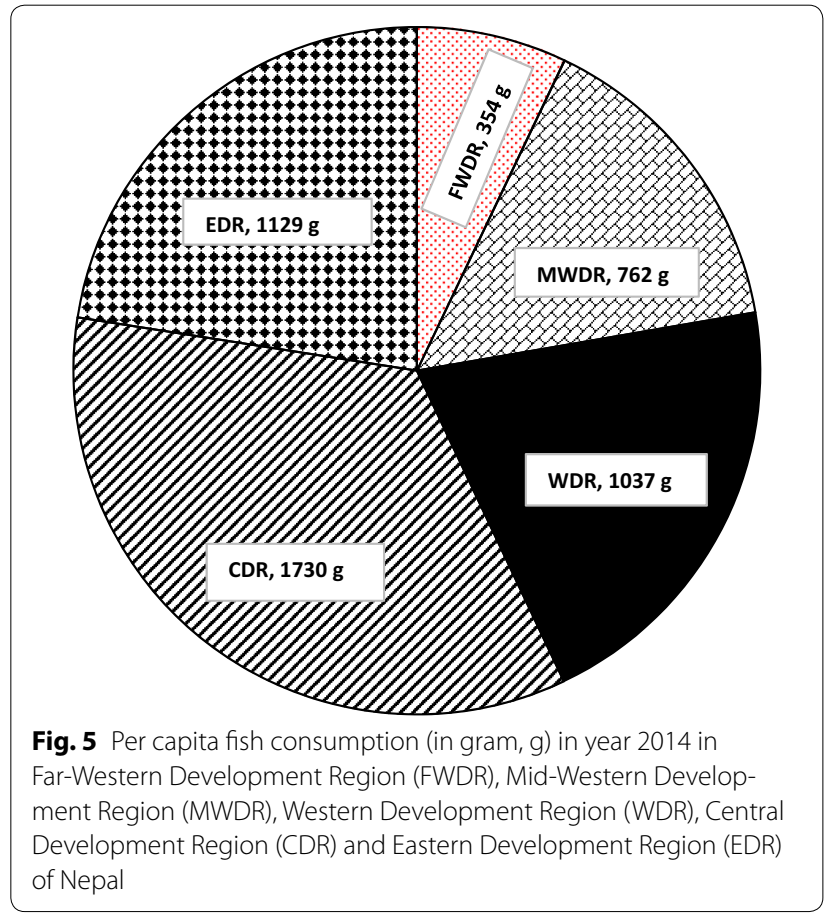

The present fish consumption in Nepal is at least nine times lower than the world per capita apparent fish consumption. The per capita world fish consumption has increased from an average of $9.9 \mathrm{~kg}$ in the $1960 \mathrm{~s}$ to $11.5 \mathrm{~kg}$ in the $1970 \mathrm{~s}, 12.5 \mathrm{~kg}$ in the $1980 \mathrm{~s}, 14.4 \mathrm{~kg}$ in the 1990s and reaching $16.4 \mathrm{~kg}$ in 2005 and 19.2 in 2012 [15]. China has accounted for most of the world growth with per capita fish supply of about $26.1 \mathrm{~kg}$ [15]. Interestingly, the global per capita increasing trend of the fish consumption showed a positive trend with economic growth, and the countries with weak economic growth have low protein intake $[15,19,42]$. 


\section{Diversity of fish foods for food and nutritional security}

In this study, various aquatic products consumed in different ecological regions of Nepal have been compiled (Table 1). Fin fish such as indigenous major carp (Labeo rohita, Cirrhinus mrigala, Catla catla), Chinese major carp (Aristichthys nobilis, Hypophthalmichthys molitrix, Ctenopharyngodon idella), Mahseer (Tor spp), Snow trout or cold water cyprinids (Shizothorax spp), Gardi Labeo dero, Tilapia (Tilapia spp), Pangas (Pangasius sp), Common carp (Cyprinus carpio), Rainbow trout (Oncorhynchus mykiss) and other minor fishes are consumed all over the country. Frogs belonging Paa liebigii and $\mathrm{Paa}$ blanfordii are also known to be eaten for various medicinal purposes by Central Himalayan hill ethnic Gurung communities [22]. Crabs are eaten in mid-hills as well as in southern tarai. Turtle are consumed occasionally by certain ethnic communities in tarai [42]. Shrimp are consumed in mountains, hill in tarai. The gastropod such as Pila (Pila globosa) and bivalve (Lammelidens marginelis) are consumed in tarai by various ethnic communities [43].

Indigenous water chest nut (Trapa sp), Makhan or foxnut (Euryale ferox), mollusk (P. globosa and L. marginelis) crustaceans, imported frozen fish, canned products and dried fish are available in market [23, 24]. Water chest nut (Trapa sp) grown in wetlands of tarai and mid-hills are fondly consumed (Table 1$)$. The makhan or foxnut $(E$. ferox) is highly valuable products used in holy occasions to worship the god. Varieties of processed fish products are sold, such as sea fish (sardine), fish pickle, fish oil capsule, fish fillet, dry fish, dry shrimp, fish meal, salted fish, fried fish and smoked fish (Table 2). But, these have not been included in the present estimate of per capita consumption (Tables 1,2).

However, the aquatic products those have not been envisaged into the per capita fish consumption, especially the indigenous products (Tables 1,2), might need to be included in future estimates. Because, according to several definitions [6] and recognition by FAO [12]

Table 1 General fishery products consumable in agroecological regions of Nepal

\begin{tabular}{llll}
\hline Fishery products & High mountains & Mid-hills & Tarai \\
\hline Fin fish & 0 & 0 & 0 \\
Frog & 0 & 0 & \\
Crab & & 0 & 0 \\
Turtle & & 0 & 0 \\
Shrimp & 0 & 0 & 0 \\
Gastropod & & & 0 \\
Bivalve & & 0 & 0 \\
Nelumbo & 0 & 0 & \\
Trapa (water chest nut) & & & 0 \\
Makhan & &
\end{tabular}

Table 2 Some processed fish food products available in Nepalese market

\begin{tabular}{ll}
\hline Products & Availability \\
\hline Sea fish (sardines) & Canned \\
Fish oil & Capsule \\
Fish fillet (Vasa) & Plastic wrapped fillet \\
Dry fish & Plastic packed/open \\
Dry shrimp and fish meal & Plastic packed/open \\
Salted fish & Plastic packed/open \\
Fried fish & Plastic packed/open \\
Smoked fish & Open \\
Fish pickle & Plastic packed \\
\hline
\end{tabular}

these commodities categorized as aquaculture products are harvested and consumed ensuring food and nutritional security and addresses the poverty alleviation. These commodities contain substantial nutritional values supporting women and children of marginalized and poor communities (Table 3). Therefore, in future research and scaling-up activities these commodities should be prioritized for production and productivity enhancement.

Substantially large quantities of fresh fishes are imported especially from India and other countries to fulfill the local demand in the capital and many others urban destinations [23]. Besides, huge amount of fish meal is imported in animal and poultry feed manufacture. The dried fish for human consumption are also imported from abroad. These all imply that the fish production has immense market opportunities in Nepal.

\section{The role of fisheries and aquaculture in macro- and micronutritional security}

The importance of fish as a rich source of animal protein is well established to justify fish as a valuable food, whereas very little attention has been given to the role and understanding of fish in supplying vitamin A and minerals in the diet $[35,47,48]$. The fish contributes substantially on macro- and micronutrients supply to human food, especially vitamin A and minerals from the different types of species [13]. Macronutrients are the energy-giving caloric components such as starch, oil and structural proteins, while micronutrients comprised of vitamins, minerals, trace elements, phytochemicals and antioxidants essential for health. The present compilation of protein contents in freshwater fish revealed a range from 14.8 to $22.8 \mathrm{~g} / 100 \mathrm{~g}$ (Table 3). High amount of protein from 58.5 to $70.8 \%$ might occur in dried fish (sundried, slated dried and smoked dry fish). The protein in crab, turtle, prawn, snail, and bivalve is also comparative 


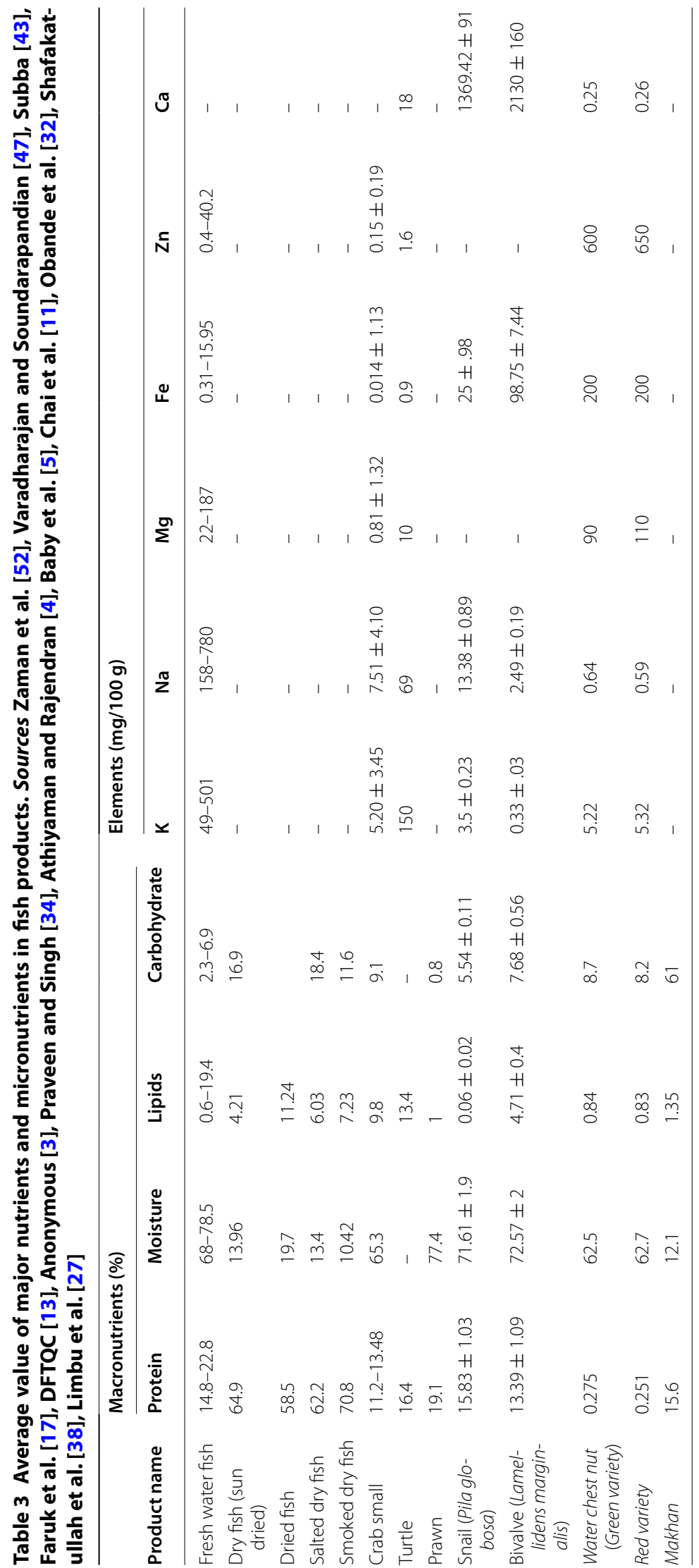


to the protein level in fin fish species (Table 3). In water chest nut, the $\mathrm{Zn}$ concentration is remarkable (Table 3).

The variation in vitamin A content in fish species is extreme [35]. The higher concentration of the vitamin $A$ is found in the eyes and viscera of fish $[13,49]$. These facts indicate that the cleaning process is highly important and might depend on the size and species of the fish for the retention of vitamin A [45]. Vitamin A in fish is found as retinol and dehydroretinol isomers [49].

Fish consumption contributes positively to adults and children's brain function, memory and improving eyesight $[25,33,49]$; particularly $\omega-3$ consumption can improve mental health and behavior disorders [1, 36, 37]. $\omega-3$ fatty acids also contribute to heart protection, Alzheimer disease $[29,33]$ and dimentia with a low $\omega-3$ fatty acid status [36]. It is stated that in the blood, $\omega-3$ polyunsaturated fatty acids produce vasodilation by reducing free fatty acids, plasma triglyceride, cholesterol concentrations and platelet aggregation [14, 49]. All these ultimately lead to decreasing blood pressure, clotting and atherosclerosis $[32,49]$. Thus, the cardio-protective role of dietary fish intake includes prevention of coronary heart disease, reduced incidence of myocardial attack, protection against thrombosis, reduced risk of sudden death and overall mortality rates [36]. Fish oil is a rich source of the $\omega-3$ fatty acids. Since our body does not efficiently produce some $\omega-3$ fatty acids, it is necessary to obtain adequate amounts through fish and fish oil products [45].

Fish is also a good source of micronutrients required for human metabolism. Much is yet to be known about the level of micronutrients and essential elements of the Himalayan fishes. In present work, only little information has been reviewed from various sources (Table 3), and detail accounts will be beyond the scope of this paper. The level of calcium $(\mathrm{Ca})$ is extremely high in snail (Pila globosa) and bivalve (Lamelliidens marginalis) compared with other organisms (Table 3) measuring up to $1369.4-2130 \mathrm{mg}$ per $100 \mathrm{~g}$ wet weight [26, 43]. Relatively high elemental level of $\mathrm{Mg}$, Fe and $\mathrm{Zn}$ was observed in water chest nut [18]. Such high or lowest elemental compositions of the commodities provide the specialty of the product and thus importance in human nutrition. A recent study found substantial support from the fish micronutrients protecting the community from mineral deficiency diseases [28].

In human nutrition, essential elements such as $\mathrm{Ca}$, magnesium $(\mathrm{Mg})$, sodium $(\mathrm{Na})$, potassium $(\mathrm{K})$, iron $(\mathrm{Fe})$, zinc $(\mathrm{Zn})$, copper $(\mathrm{Cu})$ and manganese $(\mathrm{Mn})$ are required for the normal maintenance of the human body for several biochemical reactions [10, 41]. The $\mathrm{Ca}, \mathrm{Mg}$ and phosphorus $(\mathrm{P})$ play crucial role in the formation of bones and teeth, while $\mathrm{Na}$ and $\mathrm{K}$ play role in electrolyte balance and transmission of nerve signals;
$\mathrm{Cu}, \mathrm{Zn}$ and $\mathrm{Mn}$ play the role in many enzyme reactions, and $\mathrm{Fe}$ constitutes the main parts of the hemoglobin for carrying oxygen from one place to another $[9,41]$. These elements have the direct relationship with the malnutrition problems mostly associated with the children, lactating mothers, pregnant women and pubertyattaining girls in underdeveloping poor countries in the form of stunting, retardation, underweight, anemia, osteoporosis, etc.

\section{General fish consumption pattern across Nepal}

In Nepal, the increase in fish consumption has not been uniform and adequate across regions. Nepal is a predominantly a mountainous country endowed with the tallest peak on the earth, the Mt. Everest. Earlier the people living in remote mountain villages had the poor accessibility to fish diets. People living in mountain and plain areas were known to suffer by high prevalence rate of goiter diseases [39], which may or may not be related to fish diet, but taken as the sign of lack of animal origin food and iodine deficiency in human diet. It was only lower reaches from where supply in the form of dried fish was possible to high mountain residents. Even in modern days the river valleys where rivers mouths are met, often traditional fisher's communities involving in capture fisheries supply smoked or dried hill stream fishes in small hill bazar's vegetable shop, grocery, hotel and restaurant. Contrarily, the people living in river valleys and southern plains where river water spreads over large areas provide ample opportunity for easy access to fish diets compared with mountain people. The depiction of carp paintings in walls and wood carving in door in houses in southern tarai might represent the affinity and importance of fish in their nutrition.

The analysis of fish consumption in rural areas versus urban areas would be a matter of interest; however, detail studies have yet to carry out. Generally, the major part of fresh fish sold in Kathmandu valley and other urban centers comprised of imported one from India [21]. The trends might suggest that fish consumption in urban areas is higher than in the rural.

In present study, the Central Development Region has been found to be consuming higher amount of fish (Fig. 5), while contrarily, it was the Far-Western Development Region where fish consumption was the least. This trend probably associated with the low fish production in the region and poor transportation in remote mountain districts. It is known that fish is more favorably received on the market when it is fresh, rather than processed owing to its perishable nature and limited shelf life [15].

The driving force behind the enormous surge in the consumption of animal products is a combination of population growth, rising incomes, increasing 
urbanization [15] and health awareness. Economic development and rising incomes usually lead to advances in the availability and quality of food, better overall nutritional status and the elimination of food shortages [51]. Growing urbanization usually modifies dietary patterns, both quantitatively and qualitatively, and changes the lifestyles of individuals [48]. Therefore, it is likely the role of fisheries and aquaculture production in the country would be increasing with societal dynamism in future.

\section{Conclusions}

Nepal predominantly a mountainous country is endowed with three river basins and one river system having about 6000 rivers of various lengths [21], offering opportunities for warm, cool as well as cold-water fish production. From water abundance perspectives, there could be substantial scaling up of the warm- and coldwater aquaculture. In general, the warm- and cold-water aquaculture requires rapid scaling up using plain tarai and mountain hill terraces, respectively, for fish production. In warmer tarai, aquaculture might have several agricultural enterprises in competition, but in mountain terraces, it is likely there would be rare competitor against the fish farming. If this argument is true, then it is likely that Nepal could be one of the global destinations for cold-water fish products, if feed and transportation constraints are resolved.

The standard food chart recommended $30 \mathrm{~g}$ of fish or meat protein for daily food intake [11], which is unlikely to be achieved soon with present pace of fisheries development in Nepal. Thus, more emphasis should be given to enhance the domestic fish production. Currently, Agriculture Development Perspective Plan (2015-2030) and Food and Nutrition Security Plan of Action (FNSP), the national programs for food and nutrition security [16], have emphasized the fisheries sector. Hopefully, with implementation of these national plans and policies, fisheries and aquaculture sector would further ensure the food and nutritional security in Nepal.

\section{Ethical approval and consent to participate}

It is to declare that I have all the ethical approval and consent to take participate in research paper writing and submission to any relevant journal from my organization where I am working and posted.

\footnotetext{
Abbreviations

Ca: calcium; Cu: copper; Fe: ferrous; FNSP: Food and Nutrition Security Plan of Action; g: gram; GDP: gross domestic production; $\mathrm{g} \mathrm{d}^{-1} \mathrm{yr}^{-1}$ : gram per day per year; K: potassium; kg: kilogram; Mn: manganese; Mg: magnesium; Mg: milligram; Na: sodium; N-3: $\omega-3$ fatty acids or $n-3$ fatty acids; P: phosphorus; Zn: zinc.
}

\section{Authors' contributions}

The paper is exclusively written by the author; however, most data used in the MS were collected from various secondary sources. The earlier draft of the paper was commented and reviewed by two anonymous reviewers.

\section{Authors' information}

Dr. Tek Bahadur Gurung is a Principal Scientist of Fisheries in Nepal Agricultural Research Council, presently posted as Director, National Animal Science Research Institute. Dr. Gurung was involved in fisheries research since last 30 years. His strongest contribution is the development and successful demonstration of the concept of cooperative approach of improvement of degraded lake using carps, and successful technological innovation of cold-water aquaculture in the home of Himalayas, the Nepal and surrounding countries.

\section{Acknowledgements \\ Thanks to all staffs of National Animal Science Research Institute (NASRI) for support and coordination during the preparation of this paper. The partial fund for this work has been provided by the Nepal Agricultural Research Council. The author also greatly depreciates the contribution of FAO, USAID, Asian Development Bank (ADB) and Japan International Cooperation Agency (JICA) for their supports to enhance fisheries research and development in Nepal.}

\section{Competing interests}

The authors declare that they have no competing interests

\section{Availability of supporting data}

I declare that whatever data have been used in the MS will kept remain intact until next 3 years. These data can be made available to anyone who desires to see them.

\section{Consent for publication}

It is declared that the information given in the MS now can be published by the Publication House and Journal "Agriculture and Food Security."

\section{Funding}

No particular funding for the present MS was received but was a part of regular activities of the author. Partial fund might be attributable to Nepal Agricultural Research Council where the present author is employed.

Received: 25 April 2016 Accepted: 18 July 2016

Published online: 12 August 2016

\section{References}

1. Addis PB. Omega-3 fatty acid content of Lake Superior Fish. Minneapolis: Minnesota extension service University of Minnesota, Home Economics HE-FO-561 8-b; 1990. p. 4

2. ADS Agriculture Development Strategy, Ministry of Agriculture Development, Government of Nepal 2014, p. 285.

3. Anonymous. Food nutrition facts and count calories in food. 2016. http:// slism.com/calorie/111243/.

4. Athiyaman R, Rajendran K. Nutritional value of freshwater Prawns Macrobrachium scabriculum (Heller, 1862) and Macrobrachium idellaidella (Hilgendorf, 1898). Int J Res Biol Sci. 2013;3(1):5-7. http://www.urpjournals. com.

5. Baby RL, Hasan I, Kabir KA, Naser MN. Nutrient analysis of some commercially important molluscs of Bangladesh. J Sci Res. 2010;2(2):390-6.

6. Bardach JE, Ryther JH, McLarney WO. Aquaculture, the farming and husbandry of freshwater and marine organisms. New York: Wiley-Interscience; 1972

7. Bates B, Lennox A, Prentice A, Bates C, Swan G. National diet and nutrition survey; Headline results from years 1, 2 and 3 (combined) of the rolling programme (2008/09-2010/11). 2012. https://www.gov.uk/government/ publications/national-diet-and-nutrition-survey-headline-results-fromyears-1-2-and-3-combined-of-the-rolling-programme-200809-201011. 
8. Belton B, Thilsted SH. Fisheries in transition: food and nutrition security implications for the global South. Glob Food Secur. 2014;3:59-66.

9. Beveridge MCM, Little DC. Aquaculture in traditional societies. In: CostaPierce BA, editor. Ecological aquaculture. Oxford: Blackwell; 2002.

10. Bost M, Houdart S, Oberli M, Kalonji E, Huneau J-F, Margaritis I. Dietary copper and human health: current evidence and unresolved. J Trace Elem Med Biol. 2016;35:107-15.

11. Chai T-T, Ooh K-F, Quah Y, Wong F-C. Edible freshwater macrophytes: a source of anticancer and anti-oxidative natural productsa mini-review. Phytochem Rev. 2015;14:443-57. doi:10.1007/ s11101-015-9399-z.

12. Department of Health, and Food Standards Agency, London; 2012.

13. DFTQC. Food composition table for Nepal. Kathmandu: Department of Food Technology and Quality Control Ministry of Agriculture Development, Government of Nepal; 2012. p. 80.

14. FAO. Human vitamin and mineral requirements, Report of a joint $\mathrm{FAO} /$ WHO expert consultation Bangkok, Thailand. Rome: Food and Agriculture Organization of the United Nations World Health Organization, Food and Nutrition Division, FAO; 2001. p. 289.

15. FAO. World review of fisheries and aquaculture. Rome: The State of World Fisheries and Aquaculture 2008, Food and Agriculture Organization Part 1, FAO.org; 2007. p. 84

16. FAO. The state of world fisheries \& aquaculture; 2014. p 96. http://www. fao.org/3/a-i3720e/i3720e01.pdf.

17. Faruk MO, Amin MZ, Sana NK, Shaha RK, Biswas KK. Biochemical analysis of two varieties of water chestnuts (Trapa sp.). Pak J Biol Sci. 2012;15(21):1019-26.

18. FNSP. Food and Nutrition Security Plan of Action (FNSP), A National Programme for Food and Nutrition Security, Ministry of Agriculture Development, Government of Nepal; 2013. p. 52. http://www.nnfsp.gov. np/PublicationFiles/d405d609-bb00-4708-831c-149dea4b4f49.pdf.

19. GoN. Multi-sector nutrition plan for accelerating the reduction of maternal and child under-nutrition in Nepal 2013-2017. Approved by the Cabinet Meeting of the GoN on May 15, 2012. GoN, NPC, p. 185. http:// www.npc.gov.np/images/download/MSNP_english.pdf.

20. Gordon A, Finegold C, Crissman CC, Pulis A. Fish production, consumption, and trade in Sub-Saharan Africa: a review analysis. Prepared by WorldFish, with funding from the World Bank Fish to 2030: Sub-Saharan Africa Fish Trade in a Changing Climate; 2013. p. 48. http://www.worldfishcenter.org/content/fish-production-consumption-and-trade-subsaharan-africa-review-analysis.

21. Gurung TB. Harnessing fisheries innovation for transformational impact in Nepal. Hydro Nepal. 2014;15:53-9.

22. Gurung TB, Gurung A, Doody TM. Connecting flows, fish diversity and ecology in the Koshi Basin, chap. 10. In: Doody TM, Cuddy SM, Bhatta LD, editors. Connecting flows and ecology in Nepal: current state of knowledge for the Koshi Basin. Sustainable Development Investment Portfolio (SDIP) project. Australia: CSIRO; 2016. p. 105-122. http://www. birdlifenepal.org/download-newsletter/41.

23. Gurung TB. Integrated aquaculture within agriculture irrigation for food security and adaptation to climate change. Hydro Nepal. 2012;11 (1):73-7 (Special issue: conference proceedings). http://www.nepjol.info/index. php/HN/article/view/7214/5843.

24. Gurung TB, Pradhan N, Singh DM, Thapa TB. Prospects of trout (Oncorhynchus mykiss) farming commercialization in relation to global context in Nepal: In: Gurung TB, editors. Proceedings of the workshop on scaling-up of Rainbow trout (Oncorhynchus mykiss) farming strategies in Nepal, Kathmandu, Nepal; 2008. p 158.

25. HRC. Frog consumption trend in Manaslu conservation area; 2016. http:// hrcnepal.org.np/.

26. Kromhout D, Yasuda S, Geleijnse JM, Shimokawa H. Fish oil and omega-3 fatty acids in cardiovascular disease: do they really work? Eur Heart J. 2011. doi:10.1093/eurheartj/ehr362.

27. Limbu KP, Subba BR, Rai BK. Nutritional status of three species of Molluscs in Nepal, Chapter: 10. In: Gupta VK, Verma AK, Singh GD, editors. Perspectives in animal ecology and reproduction, vol. 9. Delhi: Daya Publishing House; 2012. p. 232-9.

28. McKenzie JM, Wyness L. Review of Nutritional \& Health Benefits for the British Trout Association, Queen Margaret University, Edinburgh, British Trout Association Client Report, Edinburg; 2013. p 30
29. Mogobe O, Mosepele K, Masamba WRL. Essential mineral content of common fish species in Chanoga, Okavango Delta, Botswana, African. J Food Sci. 2015:9(9):480-6.

30. Nestel P, Clifton P, Colquhoun D, Noakes M, Mori TA, Sullivan D, Thomas B. Indications for omega-3 long chain polyunsaturated fatty acid in the prevention and treatment of cardiovascular disease. Heart Lung Circ. 2015:24:769-79.

31. NPC. Nepal thematic report on food security and nutrition 2013. Based on the findings of the Nepal living standards survey 2010/11. By, National Planning Commission, Central Bureau of Statistics in association with World Food Program, World Bank, AusAID, UNICEF; 2013 p 99.

32. Obande RA, Omeji S, Isiguzo I. Proximate composition and mineral content of the Fresh water snail (Pila ampullacea) from River Benue, Nigeria. 2013.

33. Philibert A, Fillion M, DeGuire J, Weiler H, Passos C, Lemire M, Mergler D. Plasma phospholipid omega-3 fatty acids and freshwater fish consumption in the Brazilian Amazon. Food Nutr Sci. 2013;4(9A):137-149. doi:10.4236/fns.2013.49A1021. http://www.scirp.org/journal/Paperlnformation.aspx?PaperlD=36488.

34. Praveen N, Singh AK. While effect of kinetic on protein concentration of Makhana (Euralye ferox Salisb.) during fruit development. Int J Basic Appl Sci Res. 2014:1(1):6-14.

35. Ratnayake W, Galli C. Fat and fatty acid terminology, methods of analysis and fat digestion and metabolism: a background, review paper. Ann Nutr Metab. 2009;55(1):8-43.

36. Roos N, Islamy MM, Thilsted SH. Small indigenous fish species in Bangladesh: contribution to vitamin A, calcium and iron intakes. J Nutr Am Soc Nutr Sci. 2003:4021S-6S.

37. Ruxton C, Reed S, Simpson M, Millington K. The health benefits of omega-3 polyunsaturated fatty acids: a review of the evidence. J Hum Nutr Diet. 2004;17:449-59. https://www.csuchico.edu/grassfedbeef/ research/documents/source/Ruxton\%200mega3\%20review.pdf.

38. Shafakatullah N, Shetty S, Orison R, Krishnamoorthy M. Nutritional analysis of freshwater bivalves, Lamellidens spp. from River Tunga, Karnataka, India. Res J Recent Sci. 2013;2:120-3.

39. Shrestha SM, Dixit H, Malla MM, Prasai BR, Shrestha RM, Pandey BR. Endemic goiter in Nepal. J Med Assoc Nepal. 1973;11:1-2.

40. SINA. Statistical Information on Nepalese Agriculture, Ministry of Agriculture Development, Government of Nepal; 2014. p 212. http://www.moad. gov.np/uploads/files/Year\%20book\%202014.pdf.

41. Soetan $\mathrm{KO}$, Olaiya CO, Oyewole OE. The importance of mineral elements for humans, domestic animals and plants: a review. Afr J Food Sci. 2010;4(5):200-22

42. Speedy AW. Global production and consumption of animal source foods. J Nutr. 2003;133(11):4048S-53S.

43. Subba BR. Impact of climate change on food value of molluscs in Nepal. Nepal J Biosci. 2012;2:98-108.

44. Sultana S. Flesh estimation of some sis fish. J Life Earth Sci. 2014;7:105-8.

45. Swanson D, Block R, Mousa SA. Omega-3 fatty acids EPA and DHA: health benefits throughout life. Adv Nutr. 2012;3:1-7.

46. Tacon AGJ, Matian M. Fish matters: importance of aquatic foods in human nutrition and global food supply. Rev Fish Sci. 2013;21 (1):22-38.

47. Varadharajan D, Soundarapandian P. Proximate composition and mineral contents of freshwater crab Spiralothelphusa hydrodroma (Herbst, 1794) from Parangipettai, South East Coast of India. J Aquac Res Dev. 2014;5:217.

48. Vasantha S, Vijaylakshmi S, Kiran P. Review on impact of changing lifestyles on dietary pattern. Int J Curr Aca Rev. 2015;3-6:135-47.

49. Vilain C, Baran E, Gloria G, Samadee S. Fish and the nutrition of rural cambodians. Asian J Agric Food Sci. 2016;4-1, 26-34 Asian Online J. www. ajouronline.com.

50. WHO. Joint WHO/FAO expert consultation on diet, nutrition and the prevention of chronic diseases: Geneva, Switzerland: report of a joint WHO/ FAO expert consultation. Geneva; 2002.

51. Woods B. Links between food price behavior and nutrition in the developing world. Stud Undergrad Res Guelph. 2012;5(2):51-62. https:// journal.lib.uoguelph.ca/index.php/surg/article/download/1785/2506.

52. Zaman M, Naser MN, Abdullah ATM, Khan N. Nutrient contents of some popular freshwater and Marine fish species of Bangladesh. Bangladesh J Zool. 2014:42(2):251-9. 